\title{
An Arctic Science Policy? All We Need is a Sovereignty Crisis
}

Louis-Edmond Hamelin, the famous Canadian geographer, once wrote that "Nordicity is an essential element in Canada's self-image, and...the northern frontier has repeatedly served to focus national aspirations." The Arctic has influenced our culture nationally and dominates the international perception of our country. Aboriginal land claims since 1975 and the recent creation of Nunavut reinforce the importance of the polar regions of Canada as a homeland, a fact that can only add to our identity as northern peoples. If one chose to argue against the cultural importance of the North in Canada, one would most assuredly have difficulty arguing against its importance in geographical terms. Canada is the second largest country in the world, and approximately $40 \%$ of its huge landmass lies north of the discontinuous line of permafrost. If one considers only land north of the tree line, Canada has more Arctic territory than any of the other seven Arctic nations. Canada is clearly a polar nation. In spite of this, Canadians have had, and continue to have, a rocky love affair with the Arctic, rarely expressing affection for it except when other nations encroach upon it.

During the 1999 field season, various news agencies reported on a U.S. paleontological research project undertaken in Canada's High Arctic. The project, involving a team of American scientists and one Canadian researcher working in the United States, was designed to collect data from a mummified fossil forest on Axel Heiberg Island in the Canadian Arctic Archipelago. The media coverage of the research brought out a controversy over the potential environmental impacts of the project, causing a stir among some Arctic scientists concerned about increasing foreign research in Canada's polar region. The well-funded research project (1.6 million \$Cdn) was cited by many as yet another example of how waning federal interest and budgets for Arctic research have created an environment in which Canadian research interests are increasingly superseded by their well-funded, well-organized, and well-supported foreign counterparts.

For several years now, individual scientists and associations involved in polar research have spoken candidly and eloquently about what they claim is a crisis in Arctic science and the need for a polar science policy, with little response from government. The facts do seem to speak to a severe loss of polar scientific expertise in Canada associated with budget cutbacks to polar research and logistical support, aging Arctic scientists, and fewer young academics pursuing research on northern subjects. Federal science departments, once on a par with universities for freedom in research, but with much larger budgets, have now humbled themselves to request research monies from other countries' granting agencies. As part of the deal, Canadian scientists offer to train American students in polar science specialties. The "brain drain" appears to include our best and brightest polar researchers, many of whom are spread across the United States from Alaska to New Hampshire. The lack of opportunities and funding in Canada has forced them to seek support elsewhere. The annual U.S. spending of approximately 257 million \$Cdn on Arctic research must look pretty good to a Canadian researcher used to scraping together research money from limited funding pools, including the federal government, universities, and private foundations.

The general consensus appears to be that the Canadian government has lost interest in the Arctic. However we need only to examine our history to see that Canadians, and the government as their representative, have never really been interested in Arctic science and research-that is, unless our Arctic sovereignty seemed to be threatened by a competing interest.

Successive governments dating back beyond confederation have demonstrated a fickle relationship with our polar region. The most numerous scientific expeditions in the Canadian Arctic from 1818 to 1918 were first British, then American, and finally Canadian. During that time and more recently, Norway, Sweden, and Germany also mounted significant expeditions. Unlike other nations that have explored our polar region, Canada was first pushed to conduct research in the Arctic not by scientific curiosity, but rather to assert sovereignty. In the fall of 1898, Otto Sverdrup led a Norwegian scientific expedition to survey, map, and make geological, biological, and archaeological observations that led to a claim of Norwegian sovereignty over the High Arctic Islands. In the final settlement of the Alaska boundary, the United States claimed the Alaskan panhandle from Canada on the basis of American settlement of the area. This accentuated a lingering uneasiness over the stability of other ill-defined Canadian boundaries and Canadian sovereignty in those territories lying north of the Canadian mainland. The Alaskan loss, coupled with the Norwegian claim, shook Canadian complacency. In 1903, one year after Sverdrup's return to Norway, the Canadian government decided to show some presence in the High Arctic. Over the next two decades, the exercise of Canadian sovereignty in the North was to provide the rationale for major scientific research. 
This brief time in the Arctic sunlight, as it were, was followed by a lull in Canadian Arctic research, during which time Canadian government-sponsored research was relatively rare. It was not until the latter years of World War II that Canada again looked to her northern regions. Canada's geographical location between the two superpowers of the time, the United States and the Soviet Union, was of great strategic interest to military, political, and scientific leaders. This interest and the concerns of individual Canadians regarding the significance of the North culminated in the creation of the binational Arctic Institute of North America in 1944. The Institute was incorporated by an Act of Parliament in Canada, and under the laws of New York in 1945. Despite the Institute's ensconcement in Canadian law, this was an effort spearheaded by individuals in Canada and the United States rather than by any organized government policy.

Common defence requirements increased the presence and involvement of the United States in Canada's North in the 1950s. The intensification of activity in the North brought increasing demand for scientific and technical information and for improved techniques of construction and transportation. For the first time, Canadian government agencies had to respond to foreign requests for information about the North. And often, that information was simply not available. In 1953, the Defence Research Board of Canada and the Geological Survey of Canada conducted glaciological and geological surveys along the north coast of Ellesmere Island. However, it was the launch of Sputnik that finally pushed the Canadian government to seek a presence in the Arctic, and in 1957, the Defence Research Board sponsored an extensive exploration of northern Ellesmere Island as part of Canada's contribution to the International Geophysical Year. The creation of the Polar Continental Shelf Project in 1958, along with the government-established communities of Grise Fiord and Resolute Bay, provided evidence of Canadian sovereignty.

What policy exists in regard to Canada's polar regions has evolved out of similar knee-jerk reactions. Like scientific research efforts and the logistical infrastructure for those efforts, policy has been the product of a specific event initiated by a non-Canadian actor in the Canadian Arctic. In 1969-70, the voyages of the American oil tanker Manhattan resulted in the drafting and passage of the Arctic Waters Pollution Prevention Act, among other measures to protect Canadian northern waters. Likewise, in August 1985, the voyage of the American Coast Guard icebreaker Polar Sea through the Northwest Passage acted as the defining event for the creation of Canadian Arctic maritime policy. The resulting public attention compelled the Canadian Minister of External Affairs to develop, and announce on 10 September 1985, policy initiatives that were to be the core elements of Canadian Arctic policy for the remainder of the decade.

Throughout the 1990s, with Arctic sovereignty no longer a hot issue, the government has gone silent on the issue of polar research, pausing once to create the Canadian Polar Commission, and then subsequently cutting the budgets of departments and institutions that support the discovery of polar knowledge. As we enter the 21 st century, we will undoubtedly be faced with future perceived encroachments of foreign actors on Canadian soil. Is it true that Canada's effective occupation of the Arctic will diminish with increasing foreign activity there? Can we consider the actions on Axel Heiberg last summer sufficient threat to Canadian sovereignty? If this is the case, then can we expect government, urged on by polar scientists, to respond with an Arctic science policy?

I sincerely hope that this is not the case. What we do not need is another ad hoc reactive process by our government to an immediate problem. Polar scientists should not hope that a concrete polar science policy will arise from the Axel Heiberg, or similar, controversy. Canada's governments have shown such a lack of interest in the Arctic that any reactive policy is bound to be without substance. It is clear that Canada will not support Arctic science as a distinct area of research. What we as polar scientists must do is align ourselves with the many other scientific sectors that have suffered cutbacks and lobby for the support of all science in Canada.

Our relationship with the Arctic is old enough that we should be able to maturely determine a solid course of action. Through introspection, we will discover that we have continually turned our back on our northern identity and invited other nations to discover the wonders of the Arctic and the scientific secrets it holds. Now we must look to those nations for guidance on how to effectively bring attention and funding to Canadian polar research. The only thing that will bring the Arctic back to Canada is not a quick-fix patch, but a concerted effort to mend the relationship through an integrated national science policy with an associated strategic plan, and a strategy for polar science as a component of that plan. 